\title{
Exposure dating of Late Glacial and pre-LGM moraines in the Cordon de Doña Rosa, Northern/Central Chile $\left(\sim 31^{\circ} \mathrm{S}\right)$
}

\author{
R. Zech ${ }^{1}$, Ch. Kull ${ }^{2}$, P. W. Kubik ${ }^{3}$, and H. Veit ${ }^{1}$ \\ ${ }^{1}$ Geographical Institute, University of Bern, Hallerstr. 12, 3012 Bern, Switzerland \\ ${ }^{2}$ PAGES IPO, Sulgeneckstrasse 38, 3007 Bern, Switzerland \\ ${ }^{3}$ Paul Scherrer Institute c/o Institute of Particle Physics, ETH Zurich, 8093 Zurich, Switzerland
}

Received: 10 August 2006 - Published in Clim. Past Discuss.: 25 September 2006

Revised: 6 December 2006 - Accepted: 21 December 2006 - Published: 15 January 2007

\begin{abstract}
Despite the important role of the Central Andes $\left(15-30^{\circ} \mathrm{S}\right)$ for climate reconstruction, knowledge about the Quaternary glaciation is very limited due to the scarcity of organic material for radiocarbon dating. We applied ${ }^{10} \mathrm{Be}$ surface exposure dating (SED) on 22 boulders from moraines in the Cordon de Doña Rosa, Northern/Central Chile $\left(\sim 31^{\circ} \mathrm{S}\right)$. The results show that several glacial advances in the southern Central Andes occurred during the Late Glacial between $\sim 14.7 \pm 1.5$ and $11.6 \pm 1.2 \mathrm{ka}$. A much more extensive glaciation is dated to $\sim 32 \pm 3 \mathrm{ka}$, predating the temperature minimum of the global LGM (Last Glacial Maximum: $\sim 20 \mathrm{ka}$ ). Reviewing these results in the paleoclimatic context, we conclude that the Late Glacial advances were most likely caused by an intensification of the tropical circulation and a corresponding increase in summer precipitation. High-latitude temperatures minima, e.g. the Younger Dryas (YD) and the Antarctic Cold Reversal (ACR) may have triggered individual advances, but current systematic exposure age uncertainties limit precise correlations. The absence of LGM moraines indicates that moisture advection was too limited to allow significant glacial advances at $\sim 20 \mathrm{ka}$. The tropical circulation was less intensive despite the maximum in austral summer insolation. Winter precipitation was apparently also insufficient, although pollen and marine studies indicate a northward shift of the westerlies at that time. The dominant pre-LGM glacial advances in Northern/Central Chile at $\sim 32$ ka required lower temperatures and increased precipitation than today. We conclude that the westerlies were more intense and/or shifted equatorward, possibly due to increased snow and ice cover at higher southern latitudes coinciding with a minimum of insolation.
\end{abstract}

Correspondence to: R. Zech

(roland.zech@giub.unibe.ch)

\section{Introduction}

Surface exposure dating is a new, innovative method based on in-situ production and accumulation of so-called cosmogenic nuclides (e.g. ${ }^{10} \mathrm{Be},{ }^{26} \mathrm{Al}$ and ${ }^{36} \mathrm{Cl}$ ) within the first few decimetres of an exposed rock surface (Gosse and Phillips, 2001). It can be applied to determine the deposition age of boulders and moraines, respectively. Several recent studies have shown that SED is already a powerful tool for glacial and climate reconstructions (e.g. Briner et al., 2005; Owen et al., 2005; Shulmeister et al., 2005; Smith et al., 2005).

So far, very little is known about the glaciation history in the Central Andes, mainly due to the lack of organic material for radiocarbon dating (Harrison, 2004; Heine, 2004; Veit, 2006). The Central Andes play, however, an important role in Quaternary climate reconstruction, because they are situated at the transition zone between the tropical and the mid-latitude atmospheric circulation system of the PEP I transect (Pole-Equator-Pole American Transect: www.pages.unibe.ch, Markgraf et al., 2000). Changes in the intensity or latitudinal shifts of the circulation systems should be recorded in suitable archives and provide valuable information about forcings and mechanisms of the climate system.

We have previously published results from the nearby Encierro Valley $\left(\sim 29^{\circ} \mathrm{S}, 11\right.$ samples), which indicated that a prominent glacial advance occurred during the Late Glacial ( $\sim 14.0 \pm 1.4 \mathrm{ka}$ ) (Zech et al., 2006). Several recessional moraines were deposited before deglaciation at the Pleistocene-Holocene transition $(\sim 11.6 \pm 1.2 \mathrm{ka})$. An earlier maximum glacial advance $(>24.1 \pm 2.4 \mathrm{ka})$ had tentatively been postulated based on a single boulder. Here, we now present 22 additional ${ }^{10} \mathrm{Be}$ exposure ages from moraines in the Cordon de Doña Rosa, Northern/Central Chile $\left(\sim 31^{\circ} \mathrm{S}\right.$, Fig. 1). The aim of the present study is to evaluate the previous results from the Encierro Valley. Specifically, we tried

Published by Copernicus GmbH on behalf of the European Geosciences Union. 


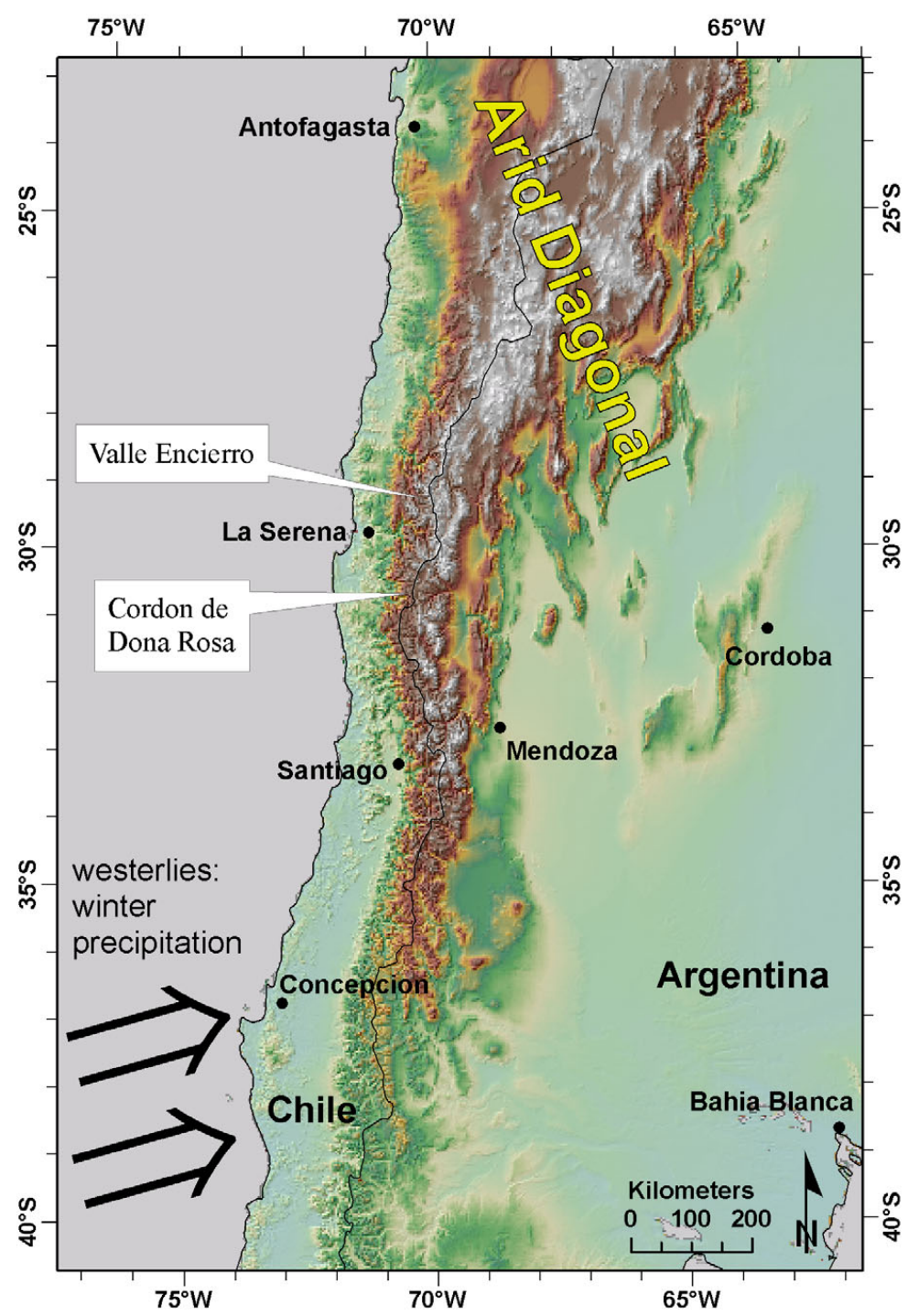

Fig. 1. Location of the research area Cordon de Doña Rosa, as well as our previous research area Valle Encierro. The westerlies provide moisture to the Central Andes south of the Arid Diagonal.

to (i) specify the succession of the Late Glacial advances and (ii) to determine the timing of the earlier, more extensive glacial advances. In addition, (iii) the paleoclimatic context has been reviewed in more detail in order to identify possible forcings on the glaciation in the southern Central Andes.

\section{Climate and paleoclimate of Northern/Central Chile}

Our research area is situated south of the "Arid Diagonal" (Fig. 1). This is the transition zone between areas in the Central Andes that are influenced by the westerlies (to the south) and areas that are influenced by the tropical circulation system (to the north). The westerlies provide moisture from the Pacific. Their seasonal northward shift results in an austral winter maximum. A steep precipitation gradient character- izes the Andean rainfall at $4000 \mathrm{~m}$ altitude: annual precipitation exceeds $4000 \mathrm{~mm}$ at $\sim 40^{\circ} \mathrm{S}$, but rapidly decreases to $\sim 2000 \mathrm{~mm}$ at $\sim 35^{\circ} \mathrm{S}$. Only $400 \mathrm{~mm} / \mathrm{a}$ are available at $\sim 30^{\circ} \mathrm{S}$, and rainfall further decreases to less than $100 \mathrm{~mm} / \mathrm{a}$ at $26^{\circ} \mathrm{S}$ (Vuille and Ammann, 1997). In the centre of the Arid Diagonal aridity becomes so severe that no glaciers exist despite altitudes $>6000 \mathrm{~m}$ a.s.l. (above sea level): that is between $18^{\circ} \mathrm{S}$ (Vulcan Sajama) and $27^{\circ} \mathrm{S}$ (Cerro Tres Cruzes) (Ammann et al., 2001). The fact that glaciers are limited by precipitation rather than temperature has been described as "thermal readiness" (Messerli, 1973). Eventually, north of the Arid Diagonal, the tropical circulation system provides moisture from the Atlantic and the Amazon Basin (Zhou and Lau, 1998: "South American Summer Monsoon" (SASM); Garreaud et al., 2003; Vuille and Keimig, 2004). 
Due to the steep humidity gradient, our research area is a key site for the reconstruction of changes in the intensity and/or shifts in the atmospheric circulation patterns. Nevertheless, knowledge about Late Quaternary glacial and climate changes in the southern Central Andes is still very limited (Garleff and Stingl, 1991; Veit, 1995; Garleff and Stingl, 1998; Espizua, 2004; Harrison, 2004; Veit, 2006). Large moraines have been mapped both north and south of the Arid Diagonal (Jenny and Kammer, 1996; Ammann et al., 2001). They document Late Pleistocene phases of substantially increased precipitation, but age control is almost absent: North of the Arid Diagonal, they have been correlated with the Late Glacial lake transgression phases, which are well-documented on the Altiplano ("Tauca": 16-14 ka; "Coipasa": 13-11 ka) (Clapperton et al., 1997; Clayton and Clapperton, 1997; Geyh et al., 1999; Sylvestre et al., 1999; Grosjean et al., 2001; Placzek et al., 2006). Evidence for a Late Glacial humid phase disappears south of $25^{\circ} \mathrm{S}$, both concerning lacustrine and glacial deposits (Geyh et al., 1999; Ammann et al., 2001). Amman et al. (2001) concluded that the maximum glacial advances north and south of the Arid Diagonal might not have occurred synchronously. The same conclusion has been deduced from a glacier-climate model that indicated a temperature depression of $\sim 5.7^{\circ} \mathrm{C}$ for the prominent moraine (M-II) in the Encierro Valley (Kull et al., 2002). This temperature depression is much stronger than the ones calculated for the Western Cordillera at $\sim 18^{\circ}$ and $23^{\circ} \mathrm{S}$ $\left(2-3^{\circ} \mathrm{C}\right)$, where the modelling results indicated very wet, relatively warm "Late Glacial" climate conditions (Kull, 1999; Kull and Grosjean, 2000). No age controls, however, have been available so far to test whether the prominent moraines south of the Arid Diagonal correlate with the LGM advances dated in the Chilean Lake District (Lowell et al., 1995; Denton et al., 1999).

As our previous dating efforts in the Encierro Valley revealed a Late Glacial age for the prominent M-II moraine (Zech et al., 2006: $\sim 14.0 \pm 1.4 \mathrm{ka}$ ) but did not allow to determine the timing of the earlier, more extensive glaciation with certainty ( $>24 \mathrm{ka}$ ), we decided to sample moraines for ${ }^{10} \mathrm{Be}$ SED in the nearby Cordon de Doña Rosa.

\section{Cordon de Doña Rosa/sampling}

The Cordon de Doña Rosa ( $30^{\circ} 42^{\prime} \mathrm{S}, 70^{\circ} 26^{\prime} \mathrm{W}$, Fig. 2) lies $\sim 200 \mathrm{~km}$ south of the Encierro Valley and $\sim 50 \mathrm{~km}$ east of the town Monte Patria. The summits reach altitudes of $\sim 4500$ ma.s.l., but no glaciers exist there today. Large prominent lateral moraines extend down to $\sim 3000 \mathrm{~m}$ a.s.l., where they just reach the east-west oriented main valley of the Rio Los Molles (DR5, DR6 and DR7, Fig. 3 Photo 1). Farther down-stream, the U-shaped-valley indicates that a former, extensive glaciation reached as deep as $<2000$ m a.s.l. (DR8, DR9 and DR10, Fig. 3 Photo 2). A complex pattern of glacial deposits can be found up-stream
(>3300 m a.s.1., DR1-4, Fig. 3 Photos 3 and 4). These recessional moraines are mostly not well-defined crest-like features, but rather flat and smooth.

We sampled (i) the prominent lateral moraines (DR5, DR6 and DR7), (ii) boulders in the main valley (DR8, DR9 and DR10) and (iii) the recessional moraines (DR1-DR4) for ${ }^{10} \mathrm{Be}$ SED (see Fig. 2 for the exact sampling location). Approximately $0.5 \mathrm{~kg}$ rock surface material was chipped from the top of the granite boulders with hammer and chisel. We followed standard sampling strategies, i.e. preferring large un-eroded boulders in a stable position. All samples were documented by photograph (see supplementary material), GPS (latitude, longitude, altitude) and a field description (including topographic shielding). The laboratory work followed standard procedures (e.g. Ivy-Ochs, 1996), i.e. in brief: separation of the quartz, dissolution in $\mathrm{HF}$ after a ${ }^{9} \mathrm{Be}$ carrier has been added, purification of beryllium using anion and cation exchange chromatography, precipitation and oxidation of beryllium. The AMS measurements were conducted by P. Kubik at the ETH/PSI tandem facility in Zurich.

\section{Results and discussion}

Exposure ages were calculated using the scaling system of Desilets and Zreda (2003) and a reference production rate of 5.25 atoms a $\mathrm{Z}^{-1} \mathrm{~g}^{-1} \mathrm{SiO}_{2}$ for neutron spallation. This value has been derived from recalculation of cosmogenic nuclide data of the Köfels landslide in Austria (Kubik et al., 1998; Kubik and Ivy-Ochs, 2004, and three unpublished data from Abramowski U., personal communication). Fast and slow muon production rates at sea level and high latitude are 0.09 and 0.11 atoms $\mathrm{a}^{-1} \mathrm{~g}^{-1}$, respectively (Heisinger et al., 2002a; Heisinger et al., 2002b). All exposure ages are corrected for changes of the magnetic field intensity (data from McElhinny and Senanayake, 1982, for the time $<10 \mathrm{ka}$; and from Guyodo and Valet, 1996, for the time $>10 \mathrm{ka}$ ). The dipole wobble is accounted for during the last $10 \mathrm{ka}$ (data according to Ohno and Hamano, 1992). Before that time, a geocentrical axial dipole can be assumed without inducing major errors. All sample data and calculated exposure ages are given in Table 1 and illustrated in their stratigraphical context in Fig. 2.

\subsection{Sample-specific effects and uncertainties}

Exposure ages of boulders do not necessarily reflect the deposition age of the respective moraine. Too old boulders can be explained with "inheritance", i.e. pre-exposure. In general, inheritance is assumed to affect less than $3 \%$ of the samples (Shanahan and Zreda, 2000; Putkonen and Swanson, 2003). On the other side, too young samples can be the result of rock surface erosion or post-depositional landform surface instability: A recent chipping event of $10 \mathrm{~cm}$, for instance, leads to an underestimation of the deposition age of $\sim 10 \%$. Concerning landform surface instability, formerly 

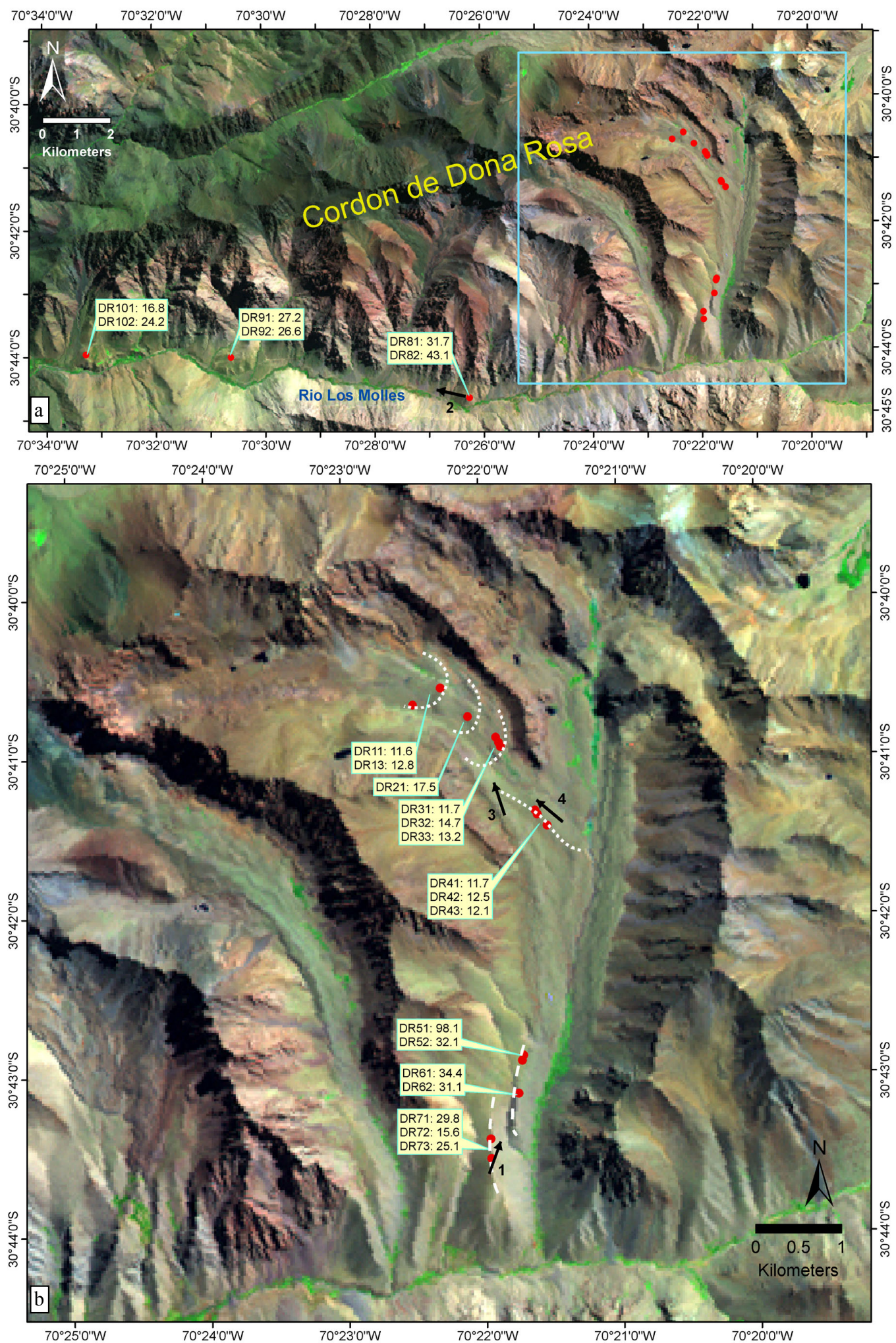

Fig. 2. Geomorphological setting of the sampling locations (red dots) and exposure ages in ka. (a) Landsat image (RGB: 742) of the Cordon de Doña Rosa with its north-south tributary valleys joining into the east-west-oriented main valley of the Rio Los Molles. (b) Close-up view of the prominent latero-frontal moraines and the recessional moraines. The dotted lines indicate terminal moraines, the dashed lines latero-frontal ones. The arrows indicate the standpoints and views of the photographs 1 to 4 . Nomenclature DRxy: DR $=$ Dona Rosa, $x=$ sampling location/moraine, $\mathrm{y}=$ sample number. 


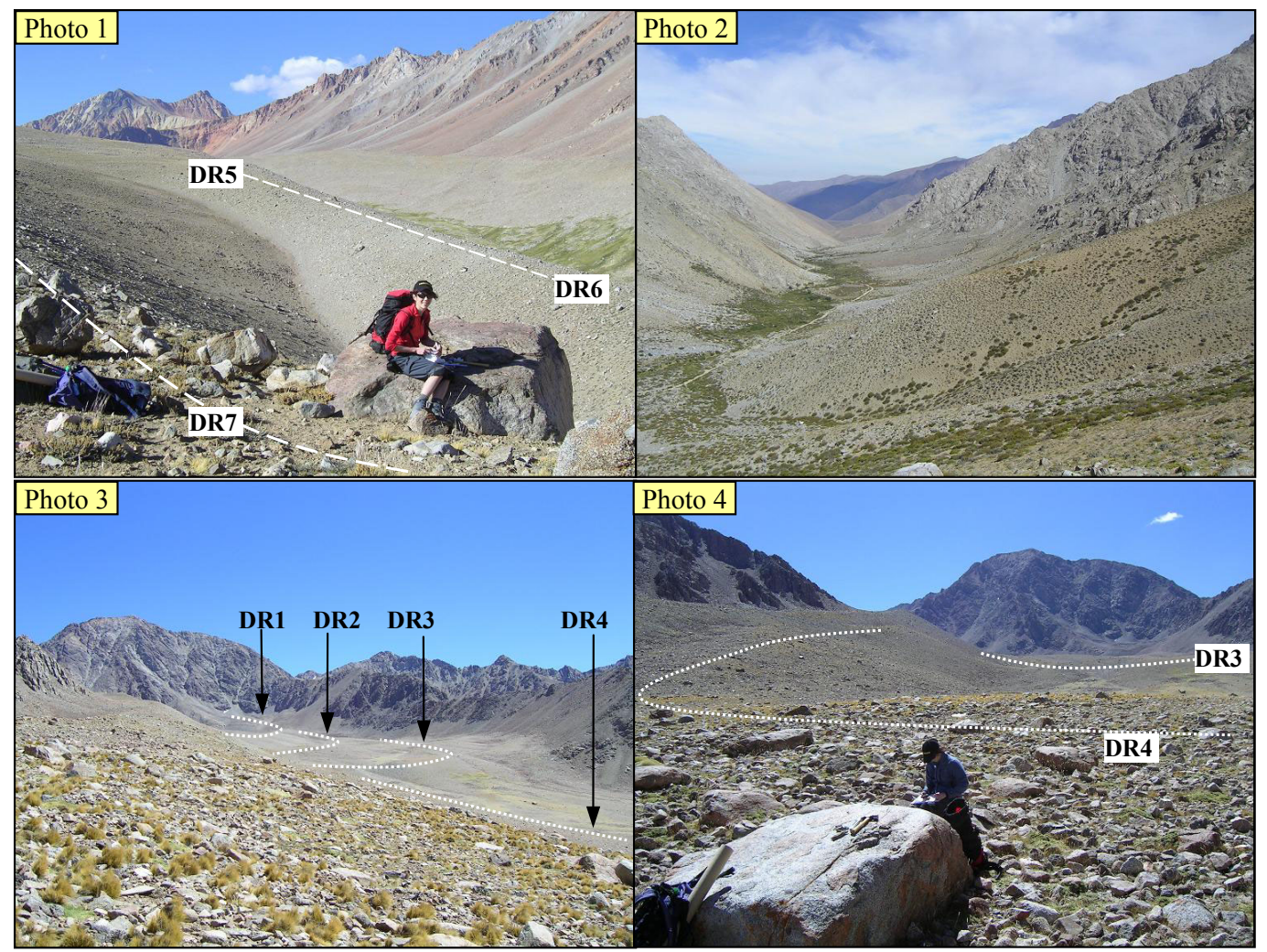

Fig. 3. Photo 1: View from the prominent latero-frontal moraine DR7 in northern direction onto the prominent lateral moraine DR6 and 5. Photo 2: View from sampling location DR8 down-valley in western direction. Note the U-shape of the valley. Photo 3: View in northern direction onto the recessional terminal moraines DR1 to 4. Photo 4: View from DR4 in north-western direction towards DR3.

shielded rock surfaces can be exposed by a wide range of geomorphological processes, like denudation of the surrounding soil matrix (Hallet and Putkonen, 1994; Putkonen and Swanson, 2003), upheaval or rotation of boulders due to cryoturbational processes, and long-lasting ice-decay in case of ice-cored moraines (Zech et al., 2005).

One can try to identify too old or too young samples based on the overall stratigraphic and chronostratigraphic situation. For this purpose, we plot all exposure ages in the order of the anticipated relative chronology, i.e. from younger to older from left to right (Fig. 4). The data scatter and the inconsistencies are due to the aforementioned sample-specific effects and the AMS measurement uncertainties (error bars). Note that negligible sample-specific effects were omitted for simplicity. These are topographic shielding $(<1 \%$, calculated according to Dunne et al., 1999), sample thickness (negligible for chips $<4 \mathrm{~cm}$, Masarik and Reedy, 1995), and vegetation and snow cover (the vegetation cover is extremely sparse and preferential sampling of large boulders minimizes snow cover effects).

\subsubsection{Late Glacial moraines}

Two boulders from the stratigraphically youngest sampled moraine have exposure ages of $11.6 \pm 0.5$ and $12.8 \pm 0.5 \mathrm{ka}$ (DR11 and DR13, respectively. Note that these are only AMS errors; systematic uncertainties are discussed later). The two ages are indistinguishable within the AMS measurement uncertainty. A single boulder has been dated from the terminal moraine DR2. Its exposure age of $17.5 \pm 0.6 \mathrm{ka}$ is rejected, because it is inconsistent with the six younger exposure ages from the moraines DR3 and DR4 down-valley ( $\rightarrow$ assumed inheritance). The terminal moraines DR3 and DR4 are dated with three exposure ages each to $11.7 \pm 0.5$ (DR31), $13.2 \pm 0.4$ (DR33) and $14.7 \pm 0.5 \mathrm{ka}$ (DR32), and to $11.7 \pm 0.6$ (DR41), 12.1 \pm 0.5 (DR43) and 12.5 $\pm 0.5 \mathrm{ka}$ (DR42).

In general, the application of the "oldest age model" can be recommended (Zech et al., 2005). It suggests that the oldest exposure age from a deposit is the best available estimate for the deposition age, unless there are stratigraphical inconsistencies. Unfortunately, this is the case for the Late Glacial moraines in the Cordon de Doña Rosa. Here, DR4 would be younger than DR3, and both would be younger than DR2. We therefore conservatively conclude that due to the sample-specific effects (especially potential inheritance vs. 
Table 1. Sample data and exposure ages calculated according to Desilets and Zreda (2003).

\begin{tabular}{|c|c|c|c|c|c|c|}
\hline Sample & $\begin{array}{c}\text { Latitude } \\
{ }^{\circ} \mathrm{S}\end{array}$ & $\begin{array}{c}\text { Longitude } \\
{ }^{\circ} \mathrm{W}\end{array}$ & $\begin{array}{l}\text { Altitude } \\
\text { [ma.s.1.] }\end{array}$ & $\begin{array}{c}{ }^{10} \mathrm{Be} \\
{\left[10^{5} \text { at/g SiO}\right.} \\
2\end{array}$ & $\begin{array}{c}\text { AMS SD }^{\mathrm{a}} \\
{[\%]}\end{array}$ & $\begin{array}{c}\text { Exposure Age } \\
{[\mathrm{ka}]^{\mathrm{b}}}\end{array}$ \\
\hline \multicolumn{7}{|c|}{ Late Glacial moraines: } \\
\hline DR11 & 30.68 & 70.37 & 3806 & 7.657 & 3.8 & $11.6 \pm 0.5$ \\
\hline DR13 & 30.68 & 70.37 & 3762 & 8.242 & 3.9 & $12.8 \pm 0.5$ \\
\hline DR21 & 30.68 & 70.37 & 3734 & 11.283 & 3.9 & $17.5 \pm 0.6$ \\
\hline DR31 & 30.68 & 70.36 & 3686 & 7.170 & 4.0 & $11.7 \pm 0.5$ \\
\hline DR32 & 30.68 & 70.36 & 3683 & 9.057 & 3.7 & $14.7 \pm 0.5$ \\
\hline DR33 & 30.68 & 70.36 & 3683 & 8.061 & 3.1 & $13.2 \pm 0.4$ \\
\hline DR41 & 30.69 & 70.36 & 3614 & 6.895 & 5.3 & $11.7 \pm 0.6$ \\
\hline DR42 & 30.69 & 70.36 & 3603 & 7.279 & 4.2 & $12.5 \pm 0.5$ \\
\hline DR43 & 30.69 & 70.36 & 3591 & 7.019 & 3.9 & $12.1 \pm 0.5$ \\
\hline \multicolumn{7}{|c|}{ Pre-LGM moraines: } \\
\hline DR51 & 30.71 & 70.36 & 3383 & 58.263 & 3.0 & $98.1 \pm 2.5$ \\
\hline DR52 & 30.72 & 70.36 & 3376 & 17.993 & 3.0 & $32.1 \pm 0.8$ \\
\hline DR61 & 30.72 & 70.36 & 3316 & 18.806 & 3.6 & $34.4 \pm 1.0$ \\
\hline DR62 & 30.72 & 70.36 & 3317 & 16.685 & 3.3 & $31.1 \pm 0.9$ \\
\hline DR71 & 30.72 & 70.37 & 3293 & 15.669 & 5.6 & $29.8 \pm 1.4$ \\
\hline DR72 & 30.72 & 70.37 & 3294 & 7.554 & 4.2 & $15.6 \pm 0.6$ \\
\hline DR73 & 30.73 & 70.37 & 3300 & 12.855 & 4.1 & $25.1 \pm 0.9$ \\
\hline \multicolumn{7}{|c|}{ Maximum glaciation: } \\
\hline DR81 & 30.75 & 70.44 & 2536 & 10.043 & 4.3 & $31.7 \pm 1.2$ \\
\hline DR82 & 30.75 & 70.44 & 2537 & 14.542 & 4.3 & $43.1 \pm 1.6$ \\
\hline DR91 & 30.73 & 70.51 & 2058 & 5.920 & 4.4 & $27.2 \pm 1.0$ \\
\hline DR92 & 30.73 & 70.51 & 2059 & 5.781 & 3.3 & $26.6 \pm 0.7$ \\
\hline DR101 & 30.73 & 70.55 & 1772 & 2.791 & 10.5 & $16.8 \pm 1.6$ \\
\hline DR102 & 30.73 & 70.55 & 1773 & 4.177 & 4.4 & $24.2 \pm 0.9$ \\
\hline
\end{tabular}

a $\mathrm{AMS} \mathrm{SD}=1 \sigma$ standard deviation of the AMS measurement

$\mathrm{b}$ including the propagated $1 \sigma$ standard deviation of the AMS measurement

erosion/landform surface instability), it seems to be impossible to determine the exact deposition age of the individual Late Glacial moraines. Glacial advances occurred between $\sim 11.6$ and $14.7 \mathrm{ka}$. Note that rejecting DR21 (17.5 ka) does not alter the general paleoclimatic interpretation. Eventually, Holocene warming (at $\sim 11.6 \mathrm{ka}$ ) initiated deglaciation, melting of buried glacier ice and stabilization of the landform surfaces.

\subsubsection{Pre-LGM moraines}

The inner prominent latero-frontal moraine was sampled close to a debris fan (DR5) and on a crest-like section (DR6). Three of four boulders date the corresponding glacial advance to $\sim 32 \mathrm{ka}$ (DR62: $31.1 \pm 0.9$, DR52: $32.1 \pm 0.8$ and DR61: $34.4 \pm 1.0 \mathrm{ka})$. The outlier DR51 (98.1 $\pm 2.5 \mathrm{ka})$ likely contains inherited ${ }^{10} \mathrm{Be}$. The outer prominent moraine (DR7) has apparently been affected more intensively by erosion. This is indicated by the smoother morphology and signs of weathering on many boulders. In fact, none of the three sampled boulders on DR7 reaches an exposure age older than the stratigraphically younger inner lateral moraine. Closest is the stable, big boulder DR71 (29.8 $\pm 1.4 \mathrm{ka})$. Boulder DR73 $(25.1 \pm 0.9 \mathrm{ka})$ is obviously eroded, and boulder DR72 $(15.6 \pm 0.6 \mathrm{ka}$, Photo DR72) is in an unstable position and might have toppled. The applicability of SED seems to have reached its limits (set by erosion and landform surface instability).

\subsubsection{Maximum glaciation}

Exposure ages from boulders on moraine remnants of the most extensive glaciation were obtained from three sites in the U-shaped main valley (DR8, DR9 and DR10). The ages range from $16.8 \pm 1.6$ (DR101) to $43.1 \pm 1.6 \mathrm{ka}$ (DR82). As evident from Fig. 4, only two ages are not inconsistent regarding the stratigraphical context. In general, all boulders show signs of weathering and are not ideally suited for SED. We conclude that it is not possible to determine the age of the most extensive glaciation. It must have occurred before $32 \mathrm{ka}$, probably much earlier, because of the intensive erosion of the moraine remnants. 


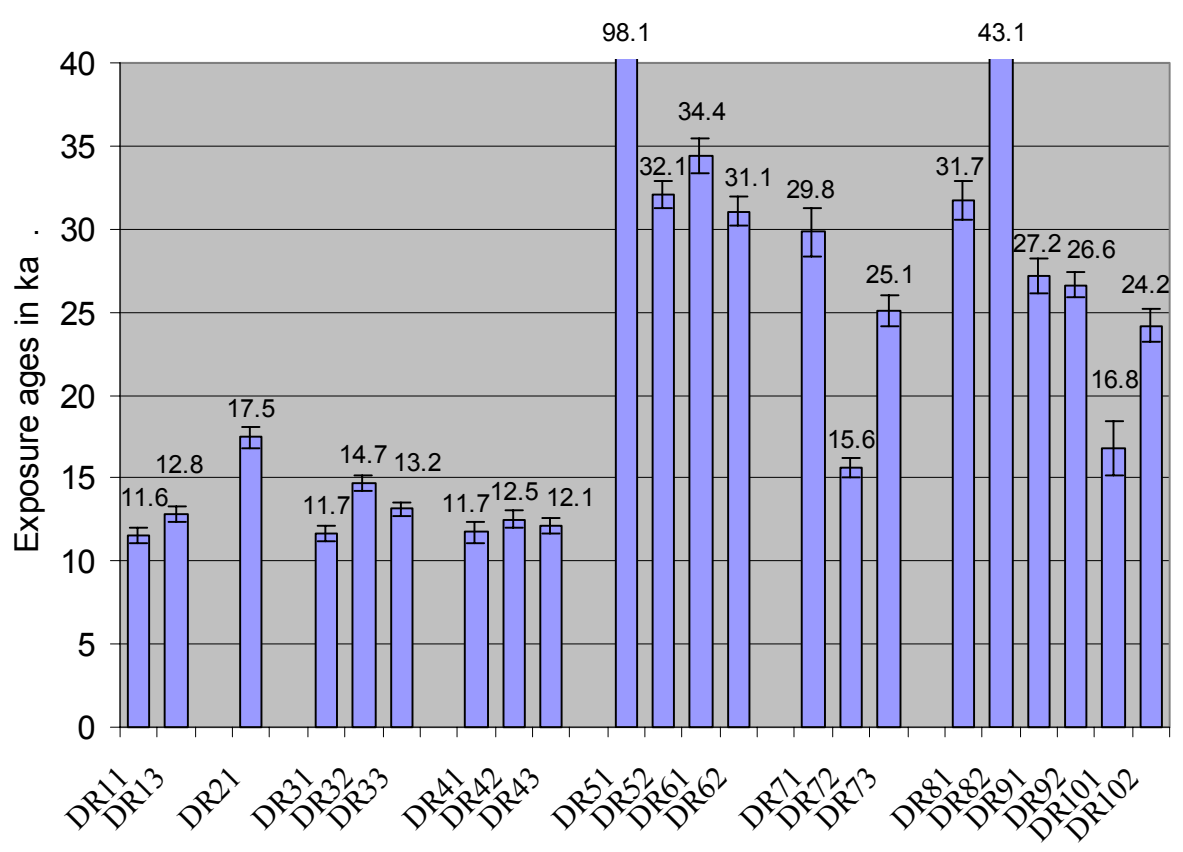

Fig. 4. Exposure age plot of all samples in the anticipated chronostratigraphic order, i.e. from younger to older from left to right. The error bars indicate the propagated $1 \sigma$ AMS measurement uncertainties.

\subsection{Systematic uncertainties}

One should be aware of the current limitations of the dating method when discussing the exposure ages in the paleoclimatic context. Systematic uncertainties, i.e. those affecting all samples in the research area in the same way, are mainly due to uncertainties concerning the reference production rate (at sea level and high latitude, SLHL, provided by calibration studies) and the scaling system. Scaling is necessary to calculate the local, effective production rate from the reference production rate and thus to account for the altitude and latitude dependence of the cosmic radiation. There is neither consensus yet concerning the exact value of the reference production rate, nor concerning scaling. A major international effort has started recently with the CRONUS-project aiming at the development of an internationally accepted protocol that will ultimately allow a precision of SED better than 5\% (CRONUS-Earth and CRONUS-EU projects: www. physics.purdue.edu/cronus, and www.cronus-eu.net, respectively). In the meantime, it is appropriate to illustrate the sensitivity of the exposure ages to various calculations schemes and assumptions. This is accomplished in Fig. 5, exemplarily for the samples DR11 and DR71.

The first columns represent the exposure ages as presented above, i.e. using the scaling system of Desilets and Zreda (2003), a reference production rate of 5.25 atoms a $\mathrm{g}^{-1}$ $\mathrm{SiO}_{2}$ for neutron spallation and geomagnetic corrections. The $10 \%$ error bars illustrate the total systematic uncertainties as suggested by Gosse and Phillips (2001). The scaling system of Dunai (2001) (second columns, using a total reference production rate of 5.51 atoms a ${ }^{-1} \mathrm{~g}^{-1} \mathrm{SiO}_{2}$ again using the cosmogenic nuclide data from the Köfels landslide, and a muon contribution of $3.6 \%$ ) yields slightly higher exposure ages. Our results are in very good agreement with the calculation scheme provided by Pigati and Lifton (2004) (third column, also using a total reference production rate based on the Köfels landslide: 5.42 atoms a ${ }^{-1} \mathrm{~g}^{-1} \mathrm{SiO}_{2}$ ). As illustrated by the fifth columns, calculations using the scaling system of Stone (2000) result in much older exposure ages. This is partly due to the fact that geomagnetic corrections are not included in that protocol. In order to enable direct comparison we therefore also did our own calculations (using the scaling system of Desilet and Zreda) excluding the geomagnetic corrections (fourth columns). This reveals that most of the offsets are due to other reasons, like the different cosmic ray dataset and the parameterisation of the neutron flux. The last columns show that even a high hypothetical constant uplift rate of $5 \mathrm{~mm} / \mathrm{a}$ would not lead to dramatic underestimation of the exposure ages and can therefore be neglected. We emphasise that arguments in favour of the scaling system of Desilet and Zreda (2003) are (i) that it is based on the bestcharacterized cosmic-ray dataset, (ii) it takes into account the altitude dependence of the energy spectrum of the cosmic radiation and (iii) it explicitly includes corrections for changes in the geomagnetic field. Nevertheless, our results may be subject to minor changes in the future. An improved understanding of the underlying physics will reduce the systematic uncertainties, and local calibration studies will be indis- 

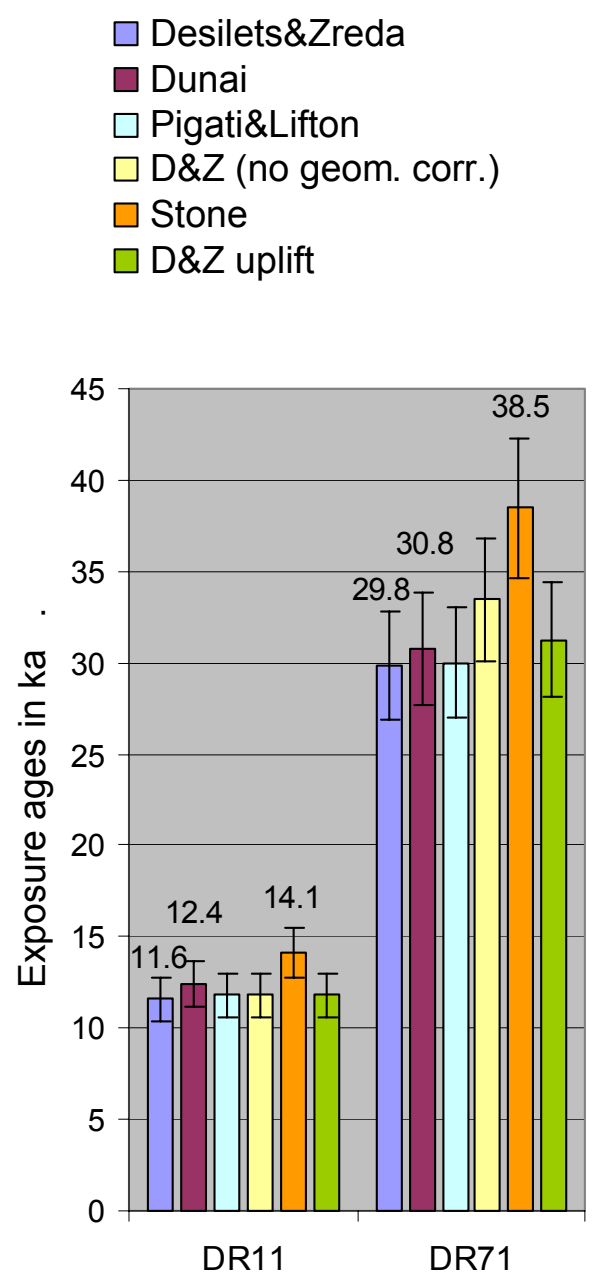

Fig. 5. Systematic uncertainties of the exposure ages. From left to right: calculation according to (1) Desilets and Zreda (2003), (2) Dunai (2001), (3) Pigati and Lifton (2004), (4) Desilets and Zreda (2003), excluding geomagnetic corrections, (5) Stone(2000) and (6) Desilets and Zreda (2003), assuming an uplift rate of $5 \mathrm{~mm} / \mathrm{a}$ (including geomagnetic corrections). The $10 \%$ error bars illustrates the total systematic uncertainties as suggested by Gosse and Phillips (2001).

pensable to address long-term atmospheric pressure anomalies and anomalies in the geomagnetic field. In the following, we quote our ages with the estimated $10 \%$ systematic error according to Gosse and Phillips (2001).

The results of the present study corroborate and supplement the glacial chronology that we have previously derived from SED in Northern/Central Chile (Zech et al., 2006):

- Glaciers were much more extensive than today during the Late Glacial between $\sim 14.7 \pm 1.5$ and $11.6 \pm 1.5 \mathrm{ka}$. Geomorphological evidence shows that several moraine stages were deposited by fluctuating glaciers. As mentioned above, the sample-specific uncertainties impede the refinement of the Late Glacial chronology.
- A large, well-defined latero-frontal moraine is dated to $\sim 32 \pm 3 \mathrm{ka}$. The timing of earlier, even more extensive glaciations cannot be determined any more with SED due to erosion.

- We find no evidence for prominent glacial advances in Northern/Central Chile during the global LGM. Of course, this does not rule out that glaciers advanced at that time, but they were limited compared to the other, datable stages.

We emphasize here that although the reader may not agree with using the scaling system of Desilets and Zreda, our general interpretation would not change. Our above interpretation of the data and the following discussion refer to glacial periods, i.e. the Late Glacial and the pre-LGM, and not to millennial-scale climate events. This would be beyond the current methodological limitations.

\subsection{Paleoclimatic context}

In the following, we discuss the glacial chronology of Northern/Central Chile in context with other paleoclimate records: first with a focus on the tropical circulation, then on the westerlies. Finally, we consider possible direct insolation forcings and the role of high-latitude temperature. Thus, we try to identify possible forcings on the glaciation and to contribute to the overall understanding of the Late Pleistocene climate changes in the Central Andes.

\subsubsection{Late Glacial advances and the increase in summer precipitation}

For the $14 \mathrm{ka}$ event in the Encierro Valley, detailed glacierclimate modelling showed that not only a temperature depression of $\sim 5.5^{\circ} \mathrm{C}$, but also an increase of annual precipitation by $\sim 580 \mathrm{~mm}$ (today $400 \mathrm{~mm}$ ) was necessary (Kull et al., 2002). Interestingly the model could not determine the seasonality of precipitation, although today predominantly winter precipitation prevails. For the reconstruction of the atmospheric circulation, it is of particular importance to determine the moisture source.

Whereas there is not much information about the Late Glacial humidity conditions south of our research area, plenty of evidence proves significantly wetter Late Glacial/Early Holocene conditions both on the Bolivian Altiplano and as far south as $28^{\circ} \mathrm{S}$ (Geyh et al., 1999; Baker et al., 2001b; Baker et al., 2001a; Grosjean et al., 2001; Placzek et al., 2006). Reservoir effects complicate the exact timing of the trangression phases, but the most recent and extensive study applied U/Th dating in combination with radiocarbon, showing that high shorelines on the Bolivian Altiplano were formed between 16-14 ("Tauca") and between 13-11 ka ("Coipasa") (Placzek et al., 2006). Glacier advances on the Altiplano have been correlated with that humid phase (Clapperton et al., 1997: Choqueyapu II glacial 


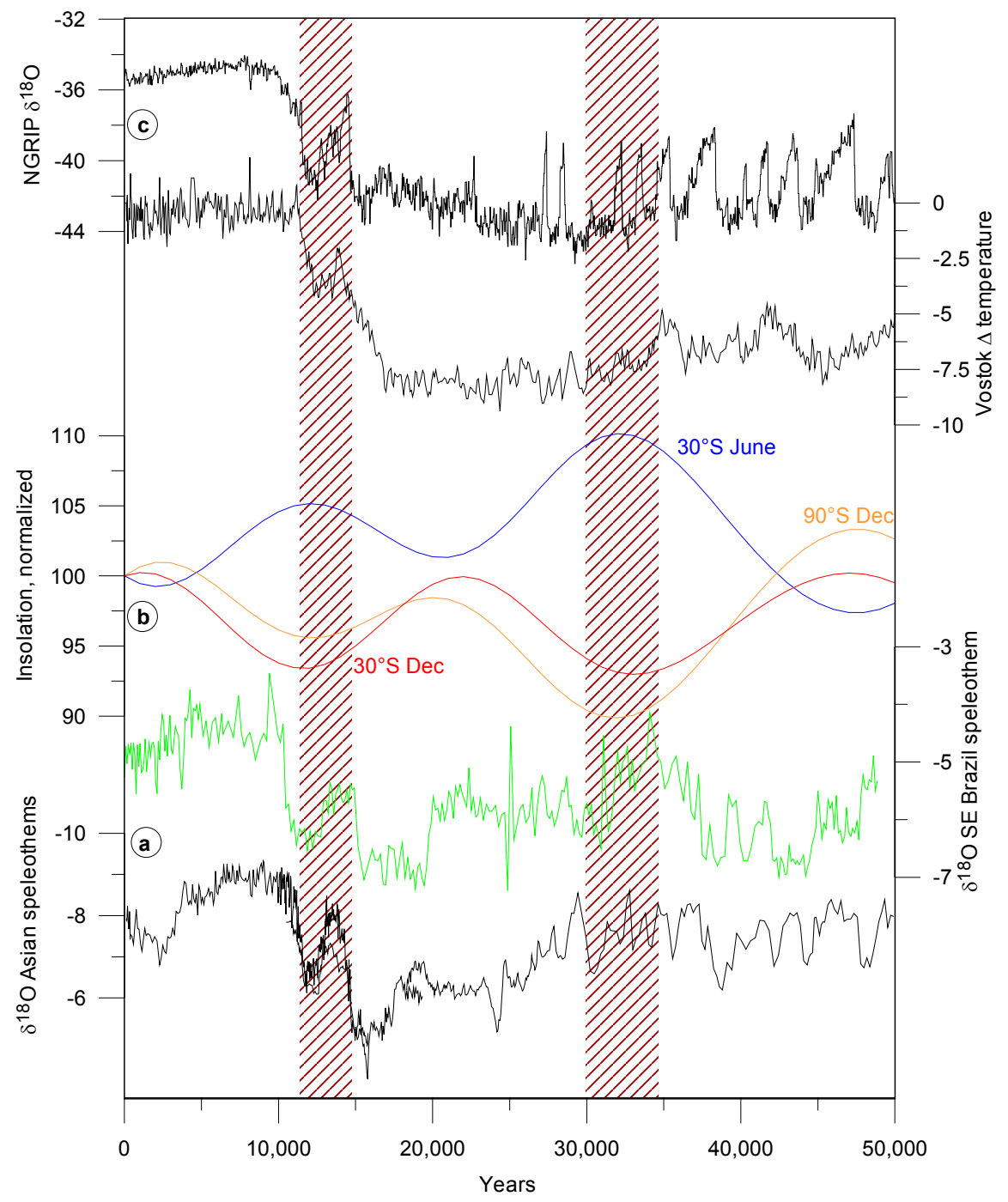

Fig. 6. Paleoclimatic context of the glacial advances in Northern/Central Chile (14.7-11.6 and 32 ka, illustrated as brown shaded bars). (a) Speleothem $\delta^{18} \mathrm{O}$ data: more negative values in the SE-Brazil speleothem indicate an intensification of the SASM (Cruz et al., 2006). The opposite signal in the Asian speleothem records from Hulu cave (Wang et al., 2001) and Dongge cave (Yuan et al., 2004) (reversed scale) illustrates the inter-hemispheric anti-phasing of monsoonal precipitation. (b) Normalized insolation changes for austral summer $\left(30^{\circ} \mathrm{S}\right.$ Dec and $\left.90^{\circ} \mathrm{S} \mathrm{Dec}\right)$ and austral winter $\left(30^{\circ} \mathrm{S}\right.$ June) (Berger and Loutre, 1991). (c) NGRIP $\delta^{18} \mathrm{O}$ record as temperature proxy for Greenland (NGRIP members, 2004, more negative values $->$ colder temperatures), and temperature deviation from present conditions in Antarctica derived from the Vostok deuterium record (Petit et al., 1999).

advances at $14-13 \mathrm{ka} \mathrm{BP}$ and $12-10 \mathrm{ka} \mathrm{BP}$, uncalibrated ${ }^{14} \mathrm{C}$ ages, see e.g. www.calpal.de for calibration). We have already previously argued that the Late Glacial advances in Northern/Central Chile at $\sim 30^{\circ} \mathrm{S}$ may have been caused by the increase in tropical moisture as well (Zech et al., 2006). This interpretation is in good agreement with pollen analyses from rodent middens in Chile at $\sim 25^{\circ} \mathrm{S}$, which indicate increased summer precipitation between 17 and $11 \mathrm{ka}$ (Maldonado et al., 2005). Moreover, speleothem data from SEBrazil can be interpreted to document the intensification of the South American Summer Monsoon (SASM) during the
Late Glacial (Wang et al., 2007; Cruz et al., 2005; Cruz et al., 2006, Fig. 6a). As illustrated in Fig. 6, relatively negative $\delta^{18} \mathrm{O}$ values in SE-Brazil correlate with more positive values in the northern hemispheric speleothems (Wang et al., 2001; Yuan et al., 2004). This documents the anti-phasing of the monsoonal precipitation, which is controlled by the hemispheric asymmetry in insolation forcing on orbital timescales and which likely also reflects millennial-scale latitudinal shift of the ITCZ due to high-latitude boundary conditions. The mechanism to transport the tropical/subtropical humidity from the South American lowlands onto the highlands of 
the Central Andes has been identified in both climate modelling and observational studies: upper-tropospheric easterly anomalies, which result from an intensification and a southward shift of the Bolivian High (Garreaud et al., 2003; Vuille and Keimig, 2004).

\subsubsection{Northward shift of the westerlies during the LGM and/or the pre-LGM?}

As is evident from the speleothem data in SE-Brazil (Cruz et al., 2006: see Fig. 6) and the shoreline studies on the Altiplano (Placzek et al., 2006), the tropical circulation system was less intensive during the LGM than during the Late Glacial. This is reflected by the absence of corresponding moraines in our research area. It was obviously too dry to allow dominant glacial advances despite the global temperature minimum. Apparently, the westerlies did not provide sufficient moisture either. Several studies have postulated a northward shift of the westerlies and increased winter precipitation in Northern/Central Chile during the LGM (e.g. Heusser, 1989; Stuut and Lamy, 2004; Maldonado et al., 2005). There are, however, still unresolved inconsistencies and controversies concerning these findings (Markgraf, 1989; Grosjean et al., 2003; Stuut et al., 2006). Climate modelling can not yet unambiguously contribute to this issue (e.g. Valdes, 2000; Wyrwoll et al., 2000). The timing and the extent of the latitudinal shifts of the westerlies clearly deserve further research.

In any case, much more precipitation than today and during the LGM was required in combination with low temperatures to trigger the massive pre-LGM advances at $\sim 32 \mathrm{ka}$ in Northern/Central Chile (preliminary results from glacierclimate modelling, Kull, 2006, personal communication). Significant contribution of tropical moisture can be excluded for that time (Cruz et al., 2006; Placzek et al., 2006), so that a northward shift and/or intensification of the westerlies can be inferred. There is glacial evidence for synchronous advances along the Central Andes as far south as $\sim 40^{\circ} \mathrm{S}$ : (1) At $36^{\circ} \mathrm{S}{ }^{40} \mathrm{Ar} /{ }^{39} \mathrm{Ar}$ dating of glaciated and unglaciated lava flows shows that pre-LGM ice caps existed and retreat started already between 25.6 and $23.3 \mathrm{ka}$ (Singer, 2000). (2) Unpublished own exposure ages from moraines in the Valle Rucachoroi ( $\sim 39^{\circ} \mathrm{S}$, Argentina) indicate that the maximum glaciation occurred at $\sim 32 \mathrm{ka}$. (3) Extensive radiocarbon dating allowed Denton et al. (1999) to demonstrate that several glacier advances occurred between $\sim 29$ and $15^{14} \mathrm{C}$ ka BP in the Chilean Lake District $\left(41-43^{\circ} \mathrm{S}\right)$. Whereas the northern parts of the Chilean Lake District experienced maximum glaciation at $\sim 22{ }^{14} \mathrm{C} \mathrm{ka} \mathrm{BP}$, the glaciers in the southern parts were most extensive at $\sim 15^{14} \mathrm{C}$ ka BP. From the overall pattern of glaciation we tentatively conclude that the westerlies, which have their focus at $\sim 50^{\circ} \mathrm{S}$ today, may have been shifted northward during the LGM with a focus at $\sim 45^{\circ} \mathrm{S}$ (e.g. Heusser, 1989; Singer, 2000; Heusser, 2003; Stuut and Lamy, 2004), but they seem to have been much more inten- sive and/or shifted north at $\sim 32 \mathrm{ka}$. This is consistent with geochemical and stable isotope analyses from the Laguna Tagua Tagua in Central Chile showing wet conditions from $\sim 40$ to $20 \mathrm{ka}$ (Valero-Garcés et al., 2005).

An explanation for the suggested shifts of the westerlies may partially be found in the Antarctic sea ice extent, which seems to play a crucial role for the latitudinal position of the westerlies according to modeling studies (Valdes, 2000; Wyrwoll et al., 2000). Mosola and Anderson (2007) and Anderson et al. (2002) dated marine sediments immediately overlying glacial till and concluded that at least parts of both the East and West Antarctic ice sheets reached their maximum extent before the LGM. We speculate that the minimum of the austral summer insolation at $\sim 30 \mathrm{ka}$ might have been the respective orbital forcing (Fig. 6b): Low insolation causing a greater sea ice extent, which in turn might have been responsible for the northward shift of the westerlies.

\subsubsection{The role of direct insolation and temperature}

Although the above described changes in atmospheric circulation most likely played the dominant role for the glaciation in the Central Andes, we want to address the potential influence of direct insolation and temperature for reasons of completeness (Kaser, 2001; Kull et al., 2002; Kull et al., 2003). The lack of high-resolution, long terrestrial temperature records from low latitudes limits this discussion to (i) the possible role of direct insolation forcing and (ii) the influence of the high-latitudes, where ice-cores provide suitable temperature proxies.

(i) As illustrated in Fig. 6, the austral summer (December) insolation at $30^{\circ} \mathrm{S}$ was at a minimum at $\sim 11.6-14.7 \mathrm{ka}$ and $\sim 32 \mathrm{ka}$, the time of the glacial advances in Northern/Central Chile. We suggest that low summer insolation led to reduced surface temperatures and reduced ablation favoring glacier growth. On the other hand, austral winter insolation at these times was quite high (see Fig. 6b). We argue that winter temperatures are not a limiting factor for glacier growth in the Central Andes. On the contrary, increased winter insolation changes the ocean-continent temperature and pressure gradient, thus favoring moisture advection and accumulation of snow and ice. Similar considerations are quite common for the summer monsoon regimes (Clemens et al., 1991; Gasse, 2000; Cruz et al., 2005). A recent modeling study corroborates the importance of the precessional forcing and resulting ocean-continent pressure gradients for low-latitude precipitation responses (Clement et al., 2004).

(ii) According to the same model of Clement et al. (2004), the low-latitude temperatures react very sensitively to highlatitude glacial forcing (polar temperatures). As is evident from the temperature proxies in Greenland and Antarctica (Fig. 6c), low temperatures prevailed not only at $\sim 20 \mathrm{ka}$, but already since $\sim 32 \mathrm{ka}$, thus allowing for the observed preLGM glacial advances in the southern Central Andes. Concerning the Late Glacial advances they coincide with reduced 
temperatures at high latitudes as well (see Fig. 6c): In Greenland a sudden return to glacial conditions is well known as the Younger Dryas (YD). In Antarctica a sudden drop in temperatures interrupts the general Late Glacial warming trend. This event slightly predates its northern-hemispheric counterpart and is known as the Antarctic Cold Reversal (ACR). Much controversy exists over the question whether climate and/or glacial events in South America were synchronous with the YD or the ACR (reviewed in: Harrison, 2004; Heine, 2004; Mark et al., 2004). As we have shown above, the systematic uncertainties currently make it impossible to resolve that debate by applying SED. Probably both highlatitude cold events had an effect on low and mid-latitude temperatures and corresponding glacial advances.

\section{Conclusions}

Surface exposure dating of moraines in the Cordon de Doña Rosa, Northern/Central Chile $\left(30^{\circ} \mathrm{S}\right)$, corroborates the results from our previous study in the Encierro Valley (Zech et al., 2006): Between $14.7 \pm 1.5$ and $11.6 \pm 1.2 \mathrm{ka}$ several glacial advances occurred, probably documenting rapid Late Glacial temperature changes, as well as very wet conditions at that time. Lake sediment studies on the Altiplano and speleothem data from SE Brazil show a substantial intensification of the tropical circulation system (Cruz et al., 2006; Placzek et al., 2006). Hitherto the influence of the tropical circulation on the southern Central Andes might have been underestimated, but the intensification and southward shift of the Bolivian High and the corresponding upper-tropospheric easterlies provide a possible mechanism to transport the moisture from the South American lowlands onto the highlands (Garreaud et al., 2003; Vuille and Keimig, 2004). The role of the westerlies during the Late Glacial requires further investigations. More dating efforts would be necessary to determine the detailed succession of Late Glacial events, because pre-exposure and landform surface instability complicate the interpretation of the exposure ages.

Although there is some paleoclimatic evidence for a northward shift of the westerlies during the LGM, no corresponding moraines could be dated. Apparently, it was too dry to allow significant glacial advances at that time. Instead, an older, extensive glaciation is dated to $\sim 32 \pm 3 \mathrm{ka}$. Increased winter precipitation can be inferred for this time. An equatorward shift of the westerlies might have been caused by the maximum extent of at least parts of the Antarctic Ice Sheets and coincides with minimum solar insolation at high southern latitudes.

Concerning the possible, but probably not so important role of direct insolation forcing, we note that austral summer insolation was low at $\sim 32 \mathrm{ka}$ and $14.7-11.6 \mathrm{ka}$. Reduced summer temperatures and reduced ablation probably favored glacier growth. On the other hand, austral winter insolation was high during these time periods. Winter temperatures, however, were probably never a limiting factor. Instead, changes in the ocean-continental temperature and pressure gradient and thus increased moisture advection could be inferred. High-latitude glacial forcing (low temperatures) probably also played an important role for the glaciation in Northern/Central Chile, both at $\sim 32 \mathrm{ka}$ and during the Younger Dryas and the Antarctic Cold Reversal, respectively.

Ongoing work applying SED aims at the determination of the spatial extent of the dated glacial advances. In combination with the glacier-climate-model, we intend to better quantify the role of temperature and precipitation. The model will have to consider seasonality in a more sophisticated way, so that the paleoclimatic interpretations can be further refined. Lastly, we highlight the need for improvements in the parameterisation of the cosmogenic radiation with regard to altitude and latitude scaling, as well as the need for calibration sites in the Central Andes in order to reduce the current systematic uncertainties of SED.

Photographs from all sampled boulders are provided as supplementary material (http://www.clim-past.net/3/1/2007/ cp-3-1-2007-supplement.pdf).

Acknowledgement. We would like to thank the Swiss National Science Foundation for funding (SNF project 21-067937.02/1), and M. Vuille and N. Lifton for helpful discussions. R. Z. gratefully acknowledges the support by the "Studienstiftung des deutschen Volkes e.V."

Edited by: M. Fuchs

\section{References}

Ammann, C., Jenny, B., Kammer, K., and Messerli, B.: Late Quaternary Glacier response to humidity changes in the arid Andes of Chile (18-29 S), Palaeogeography, Palaeoclimatology, Palaeoecology, 172, 313-326, 2001.

Anderson, J. B., Shipp, S. S., Lowe, A. L., Wellner, J. S., and Mosola, A. B.: The Antarctic Ice Sheet during the Last Glacial Maximum and its subsequent retreat history: a review, Quat. Sci. Rev., 21(1-3), 49-70, 2002.

Baker, P. A., Rigsby, C. A., Seltzer, G. O., Fritz, S. C., Lowenstein, T. K., Bacher, N. P., and Veliz, C.: The history of South American tropical precipitation for the past 25,000 years, Science, 291, 640-643, 2001a.

Baker, P. A., Rigsby, C. A., Seltzer, G. O., Fritz, S. C., Lowenstein, T. K., Bacher, N. P., and Veliz, C.: Tropical climate changes at millennial and orbital timescales on the Bolivian Altiplano, Nature, 409, 698-701, 2001b.

Berger, A. and Loutre, M. F.: Insolation values for the climate of the last 10 million of years, Quat. Sci. Rev., 10(4), 297-317, 1991.

Briner, J. P., Kaufman, D. S., Manley, W. F., Finkel, R. C., and Caffee, M. W.: Cosmogenic exposure dating of late Pleistocene moraine stabilization in Alaska, GSA Bulletin, 117(7), 1108$1120,2005$.

Clapperton, C. M., Clayton, J. D., Benn, D. I., Marden, C. J., and Argollo, J.: Late Quaternary glacier advances and palaeolake 
highstands in the Bolivian Altiplano, Quaternary International, 38-39, 49-59, 1997.

Clayton, J. D. and Clapperton, C. M.: Broad Synchrony of a LateGlacial Glacier Advance and the Highstand of Palaeolake Tauca in the Bolivian Altiplano, Journal of Quaternary Science, 12, 169-182, 1997.

Clemens, S., Prell, W., Murray, D., Shimmield, G. and Weedon, G.: Forcing mechanisms of the Indian Ocean monsoon, Nature, 353, 720-725, 1991.

Clement, A. C., Hall, A., and Broccoli, A. J.: The importance of precessional signals in the tropical climate, Climate Dynamics, 22(4), 327-341, 2004

Cruz, F. W., Burns, S. J., Karmann, I., Sharp, W. D., Vuille, M., Cardoso, A. O., Ferrari, J. A., Silva Dias, P. L., and Viana, O.: Insolation-driven changes in atmospheric circulation over the past 116,000 years in subtropical Brazil, Nature, 434, 63-66, 2005.

Cruz, F. W., Burns, S. J., Karmann, I., Sharp, W. D., and Vuille, M.: Reconstruction of regional atmospheric circulation features during the late Pleistocene in subtropical Brazil from oxygen isotope composition of speleothems, Earth Planet. Sci. Lett., 248(1-2), 495-507, 2006

Denton, G. H., Lowell, T. V., Heusser, C. J., Schlüchter, C., Andersen, B. G., Heusser, L. E., Moreno, P. I., and Marchant, D. R.: Geomorphology, stratigraphy, and radiocarbon chronology of Llanquihue drift in the area of the southern Lake District, Seno Reloncavi, and Isla Grande de Chiloe, Chile, Geografiska Annaler, 81(A), 167-229, 1999.

Desilets, D. and Zreda, M.: Spatial and temporal distribution of secondary cosmic-ray nucleon intensities and applications to in situ cosmogenic dating, Earth Planet. Sci. Lett., 206, 21-42, 2003.

Dunai, T. J.: Influence of secular variation of the geomagnetic field on production rates of in situ produced cosmogenic nuclides, Earth Planet. Sci. Lett., 193, 197-212, 2001.

Dunne, A., Elmore, D., and Muzikar, P.: Scaling factors for the rates of production of cosmogenic nuclides for geometric shielding and attenuation at depth on sloped surfaces, Geomorphology, 27, 3-11, 1999.

Espizua, L. E.: Pleistocene glaciations in the Mendoza Andes, Argentina, in: Quaternary Glaciations - Extent and Chronology. Part III: South America, Asia, Africa, Australasia, Antarctica, edited by: Ehlers, J. and Gibbard, P. L., Cambridge, 2004.

Garleff, K. and Stingl, H. (Eds.): Südamerika: Geomorphologie und Paläoökologie im jüngeren Quartär, Bamberger Geographische Schriften, 11, 1991 .

Garleff, K. and Stingl, H. (Eds.): Landschaftsentwicklung, Paläoökologie und Klimageschichte der Ariden Diagonale Südamerikas im Jungquartär, Bamberger Geographische Schriften, 15, 1998.

Garreaud, R., Vuille, M., and Clement, A. C.: The climate of the Altiplano: observed current conditions and mechanisms of past changes, Palaeogeography, Palaeoclimatology, Palaeoecology, 194(1-3), 5-22, 2003.

Gasse, F.: Hydrological changes in the African tropics since the Last Glacial Maximum, Quat. Sci. Rev., 19, 189-211, 2000.

Geyh, M. A., Grosjean, M., Nunez, L., and Schotterer, U.: Radiocarbon Reservoir Effect and the Timing of the Late-Glacial/Early Holocene Humid Phase in the Atacama Desert (Northern Chile), Quaternary Research, 52, 143-153, 1999.
Gosse, J. C. and Phillips, F. M.: Terrestrial in situ cosmogenic nuclides: theory and application, Quat. Sci. Rev., 20, 1475-1560, 2001.

Grosjean, M., Cartajena, I., Geyh, M. A., and Nunez, L.: From proxy data to paleoclimate interpretation: the mid-Holocene paradox of the Atacama Desert, northern Chile, Palaeogeography, Palaeoclimatology, Palaeoecology, 194(1-3), 247-258, 2003.

Grosjean, M., Van Leeuwen, J. F. N., Van Der Knaap, W. O., Geyh, M. A., Ammann, B., Tanner, W., Messerli, B., and Veit, H.: A 22,000 14C yr BP sediment and pollen record of climate change from Laguna Miscanti 231S, northern Chile, Global and Planetary Change, 28, 35-51, 2001

Guyodo, Y. and Valet, J.-P.: Relative variations in geomagnetic intensity from sedimentary records: the past 200.000 years, Earth Planet. Sci. Lett., 143, 23-26, 1996.

Hallet, B. and Putkonen, J.: Surface dating of dynamic landforms: young boulders on aging moraines, Science, 265, 937-940, 1994.

Harrison, S. P.: The Pleistocene glaciations of Chile, in: Quaternary Glaciations - Extent and Chronology. Part III: South America, Asia, Africa, Australasia, Antarctica, edited by: Ehlers, J. and Gibbard, P. L., Cambridge, 2004.

Heine, K.: Late Quaternary glaciations of Bolivia, in: : Quaternary Glaciations - Extent and Chronology. Part III: South America, Asia, Africa, Australasia, Antarctica, edited by: Ehlers, J. and Gibbard, P. L., Cambridge, 2004.

Heisinger, B., Lal, D., Jull, A. J. T., Kubik, P., Ivy-Ochs, S., Knie, K., and Nolte, E.: Production of selected cosmogenic radionuclides by muons 2. Capture of negative muons, Earth Planet. Sci. Lett., 200, 357-369, 2002a.

Heisinger, B., Lal, D., Jull, A. J. T., Kubik, P., Ivy-Ochs, S., Neumaier, S., Knie, K., Lazarev, V., and Nolte, E.: Production of selected cosmogenic radionuclides by muons 1. Fast muons, Earth Planet. Sci. Lett., 200, 345-355, 2002b.

Heusser, C. J.: Southern westerlies during the last glacial maximum, Quaternary Research, 31, 423-425, 1989.

Heusser, C. J.: Ice Age Southern Andes - A Chronicle of Paleoecological Events, Elsevier, pp. 240, 2003.

Ivy-Ochs, S.: The dating of rock surface using in situ produced $10 \mathrm{Be}, 26 \mathrm{Al}$ and $36 \mathrm{Cl}$, with examples from Antarctica and the Swiss Alps, Dissertation ETH No. 11763, Zürich, 197 pp., 1996.

Jenny, B. and Kammer, K.: Climate Change in den trockenen Anden: Jungquartäre Vergletscherung, Geographica Bernensia, G46, 1-80, 1996.

Kaser, G.: Glacier-climate interaction at low latitudes, Journal of Glaciology, 47(157), 195-204, 2001.

Kubik, P. and Ivy-Ochs, S.: A re-evaluation of the $0-10 \mathrm{ka} 10 \mathrm{Be}$ production rate for exposure dating obtained from the Köfels (Austria) landslide, Nuclear Instruments and Methods in Physics Research B, 223-224, 618-622, 2004.

Kubik, P. W., Ivy-Ochs, S., Masarik, J., Frank, M., and Schlüchter, C.: $10 \mathrm{Be}$ and $26 \mathrm{Al}$ production rates deduced from an instantaneous event within the dendro-calibration curve, the landslide of Köfels, Ötz Valley, Austria, Earth Planet. Sci. Lett., 161, 231241, 1998.

Kull, C.: Modellierung paläoklimatischer Verhältnisse basierend auf der jungpleistozänen Vergletscherung in Nordchile - Ein Fallbeispiel aus den Nordchilenische Anden, Z. Gletscherk. Glazialgeol., 35, 35-64, 1999. 
Kull, C. and Grosjean, M.: Late Pleistocene climate conditions in the North Chilean Andes drawn from a Climate-Glacier Model, Journal of Glaciology, 46, 622-632, 2000.

Kull, C., Grosjean, M., and Veit, H.: Modeling Modern and Late Pleistocene Glacio-Climatological Conditions in the North Chilean Andes (29-30 ), Climatic Change, 52, 359-381, 2002.

Kull, C., Hanni, F., Grosjean, M., and Veit, H.: Evidence of an LGM cooling in NW-Argentina $\left(22^{\circ} \mathrm{S}\right)$ derived from a glacier climate model, Quaternary International, 108(1), 3-11, 2003.

Lowell, T. V., Heusser, C. J., Andersen, B. G., Moreno, P. I., Hauser, A., Heusser, L. E., Schlüchter, C., Marchant, D. R., and Denton, G. H.: Interhemispheric correlations of Late Pleistocene glacial events, Science, 269, 1541-1549, 1995.

Maldonado, A., Betancourt, J. L., Latorre, C., and Villagran, C.: Pollen analyses from a 50000 -yr rodent midden series in the southern Atacama Desert (2530' S), Journal of Quaternary Science, 20(5), 493-507, 2005.

Mark, B. G., Seltzer, G. O., and Rodbell, D. T.: Late Quaternary glaciations of Ecuador, Peru and Bolivia, in: Quaternary Glaciations - Extent and Chronology. Part III: South America, Asia, Africa, Australasia, Antarctica, edited by: Ehlers, J. and Gibbard, P. L., Cambridge, 2004.

Markgraf, V.: Reply to C. J. Heusser's "Southern Westerlies during the Last Glacial Maximum”, Quaternary Research, 28, 426-432, 1989.

Markgraf, V., Baumgartner, T. R., Bradbury, J. P., Diaz, H. F., B. Dunbar, R., Luckman, B. H., Seltzer, G. O., Swetnam, T. W., and Villalba, R.: Paleoclimate reconstruction along the Pole-EquatorPole transect of the Americas (PEP 1), Quat. Sci. Rev., 19(1-5), 125-140, 2000.

Masarik, J. and Reedy, R. C.: Terrestrial cosmogenic-nuclide production systematics calculated from numerical simulations, Earth Planet. Sci. Lett., 136, 381-395, 1995.

Mcelhinny, M. W. and Senanayake, W. E.: Variations in the geomagnetic dipole 1: The past 50.000 years, Journal of Geomagnetism and Geoelectricity, 34, 39-51, 1982.

Messerli, B.: Problems of vertical and horizontal arrangement in the high mountains of the extreme arid zone (Central Sahara), Arctic and Alpine Research, 5(A), 139-47, 1973.

Mosola, A. B. and Anderson, J. B.: Expansion and rapid retreat of the West Antarctic Ice Sheet in eastern Ross Sea: possible consequence of over-extended ice streams?, Quat. Sci. Rev., 25(1718), 2177-2196, 2006.

Ngrip Members: High-resolution record of Northern Hemisphere climate extending into the last interglacial period, Nature, 431, 147-151, 2004.

Ohno, M. and Hamano, Y.: Geomagnetic poles over the past 10.000 years, Geophys. Res. Lett., 19, 1715-1718, 1992.

Owen, L. A., Finkel, R. C., Barnard, P. L., Haizhou, M., Asahi, K., Caffee, M. W., and Derbyshire, E.: Climatic and topographic controls on the style and timing of Late Quaternary glaciation throughout Tibet and the Himalaya defined by 10Be cosmogenic radionuclide surface exposure dating, Quat. Sci. Rev., 24(12-13), 1391-1411, 2005.

Petit, J. R., Jouzel, J., Raynaud, D., Barkov, N. I., Barnola, J.-M., Basile, I., Bender, M., Chappellaz, J., Davis, M., Delaygue, G., Delmotte, M., Kotlyakov, V. M., Legrand, M., Lipenkov, V. Y., Lorius, C., Pepin, L., Ritz, C., Saltzman, E., and Stievenard, M.: Climate and atmospheric history of the past 420,000 years from the Vostok ice core, Antarctica, Nature, 399(6735), 429-436, 1999.

Pigati, J. S. and Lifton, N. A.: Geomagnetic effects on timeintegrated cosmogenic nuclide production with emphasis on in situ 14C and 10Be, Earth Planet. Sci. Lett., 226, 193-205, 2004.

Placzek, C., Quade, J., and Patchett, P. J.: Geochronology and stratigraphy of late Pleistocene lake cycles on the southern Bolivian Altiplano: Implications for causes of tropical climate change, GSA Bulletin, 118(5), 515-532, 2006.

Putkonen, J. and Swanson, T.: Accuracy of cosmogenic ages for moraines, Quaternary Research, 59, 255-261, 2003.

Shanahan, T. M. and Zreda, M.: Chronology of Quaternary glaciations in East Africa, Earth Planet. Sci. Lett., 177, 23-42, 2000.

Shulmeister, J., Fink, D., and Augustinus, P. C.: A cosmogenic nuclide chronology of the last glacial transition in North-West Nelson, New Zealand-new insights in Southern Hemisphere climate forcing during the last deglaciation, Earth Planet. Sci. Lett., 233(3-4), 455-466, 2005.

Singer, B.: 40Ar/39Ar evidence for early deglaciation of the central Chilenian Andes, Geophysical Research Letters, 27(11), 16631666, 2000.

Smith, J. A., Seltzer, G. O., Farber, D. L., Rodbell, D. T., and Finkel, R. C.: Early Local Last Glacial Maximum in the Tropical Andes, Science, 308, 678-681, 2005.

Stone, J. O.: Air pressure and cosmogenic isotope production, J. Geophys. Res., 105, 23 753-23 759, 2000.

Stuut, J.-B. W. and Lamy, F.: Climate variability at the southern boundaries of the Namib (southwestern Africa) and Atacama (northern Chile) coastal deserts during the last 120,000 yr, Quaternary Research, 62(3), 301-309, 2004.

Stuut, J.-B. W., Marchant, D. R., Kaiser, J., Lamy, F., Mohtadi, M., Romero, O. E., and Hebbeln, D.: The Late Quaternary paleoenvironment of Chile as seen from marine archives, Geographica Helvetica, 61, 135-151, 2006.

Sylvestre, F., Servant, M., Servant-Vildary, S., Causse, C., Fournier, M. and Ybert, J.-P.: Lake-Level Chronology on the Southern Bolivian Altiplano (18-23 S) during Late-Glacial Time and the Early Holocene, Quaternary Research, 51, 54-66, 1999.

Valdes, P. J.: South American palaeoclimate model simulations: how reliable are the models?, Journal of Quaternary Science, 15(4), 357-368, 2000.

Valero-Garcés, B. L., Jenny, B., Rondanelli, M., Delgado-Huertas, A., Burns, S. J., Veit, H., and Moreno, A.: Palaeohydrology of Laguna de Tagua Tagua ( $34^{\circ} 30^{\prime} \mathrm{S}$ ) and moisture fluctuations in Central Chile for the last $46000 \mathrm{yr}$, Journal of Quaternary Science, 20(7-8), 625-641, 2005.

Veit, H.: Jungquartäre Landschafts- und Klimaentwicklung der zentralen Anden und ihres westlichen Vorlandes: Kenntnisse und Probleme, Geomethodica, 20, 163-194, 1995.

Veit, H.: Quartäre Landschaft- und Klimageschichte Südamerikas, in: Naturraum Lateinamerika, edited by: Borsdorf, A. and Hödl, W., Wien, 2006.

Vuille, M. and Ammann, C.: Regional Snowfall Patterns in the High, Arid Andes (South America), Clim. Change, 36, 413-423, 1997.

Vuille, M. and Keimig, F.: Interannual Variability of Summertime Convective Cloudiness and Precipitation in the Central Andes Derived from ISCCP-B3 Data, J. Clim., 17(17), 3334-3348, 2004. 
Wang, X., Auler, A. S., Edwards, R. L., Cheng, H., Ito, E., and Solheid, M.: Interhemispheric anti-phasing of rainfall during the last glacial period, Quat. Sci. Rev., in press, 2007.

Wang, Y. J., Cheng, H., Edwards, R. L., An, Z. S., Wu, J. Y., Shen, C.-C., and Dorale, J. A.: A High-Resolution Absolute-Dated Late Pleistocene Monsoon Record from Hulu Cave, China, Science, 294(5550), 2345-2348, 2001.

Wyrwoll, K.-H., Dong, B., and Valdes, P.: On the Position of Southern Hemisphere Westerlies at the Last Glacial Maximum: An Outline of AGCM Simulation Results and Evaluation of their Implications, Quat. Sci. Rev., 19, 881-898, 2000.

Yuan, D., Cheng, H., Edwards, R. L., Dykoski, C. A., Kelly, M. J., Zhang, M., Qing, J., Lin, Y., Wang, Y., Wu, J., Dorale, J. A., An, Z., and Cai, Y.: Timing, Duration, and Transitions of the Last Interglacial Asian Monsoon, Science, 304(5670), 575-578, 2004.
Zech, R., Glaser, B., Sosin, P., Kubik, P. W., and Zech, W.: Evidence for long-lasting landform surface instability on hummocky moraines in the Pamir Mountains from surface exposure dating, Earth Planet. Sci. Lett., 237, 453-461, 2005.

Zech, R., Kull, C., and Veit, H.: Late Quaternary glacial history in the Encierro Valley, Northern Chile $\left(29^{\circ} \mathrm{S}\right)$, deduced from 10Be surface exposure dating, Palaeogeography, Palaeoclimatology, Palaeoecology, 234(2-4), 277-286, 2006.

Zhou, J. and Lau, K.-M.: Does a monsoon climate exist over South America?, J. Clim., 11(5), 1020-1040, 1998. 